\title{
The Citadel of Turin: geometric design and underground archaeological evidence
}

\author{
Roberta Spallone $^{\text {a }}$, Fabrizio Zannoni ${ }^{\text {b }}$ \\ ${ }^{\text {a }}$ Politecnico di Torino, Turin, Italy, roberta.spallone@ polito.it \\ ${ }^{\mathrm{b}}$ Associazione Museo Pietro Micca, Turin, Italy, fabriziozannoni@yahoo.it
}

\begin{abstract}
The Citadel of Turin (1564) is one of the first pentagonal modern fortification. For over two centuries it was the fulcrum of Turin defences, finally unarmed and largely dismantled during the second half of the nineteenth century. However, the lower sections of main defences and detached works were spared and buried inside the filled ditches, as well as the underground countermine system. Significant historical drawings, documenting the building of external defences are selected aiming to recognize geometric criteria that rules the subsequent phases, and to relate the designed fortification with the archaeological evidence.
\end{abstract}

Keywords: Geometry, graphical analysis, archaeological investigation, conflict archaeology.

\section{Introduction}

The Citadel of Turin, designed by Francesco Paciotto and built from 1564, is one of the first and most famous examples of pentagonal modern fortification. The new fortress, whose design is featured by the rigorous concatenation of defensive elements that expresses the close link between architecture, geometry and ballistics, became operative since 1566 , with the placement of the first artillery. For over two centuries it was the fulcrum of Turin defences, finally unarmed and largely dismantled during the second half of the nineteenth century. However, the lower sections of main defences and detached works were spared and buried inside the filled ditches, as well as the underground countermine system. Significant drawings, which document the succession of interventions to build the belt of external defences between the siege of 1640 and the early $18^{\text {th }}$ century, and one of the first half of the $19^{\text {th }}$ century, just before the partial demolition of the above-ground parts, were se- lected. They are the object of graphical analysis through digital re-drawing, aimed to hypothesize the geometric criteria that rules the subsequent construction phases, and to relate the designed fortification with the archaeological evidence, today the subject of systematic recovery, study and enhancement from the 1950s.

\section{Architecture, geometry and ballistics in the historical drawings of the Citadel}

When possible, the selected original drawings were analysed and directly reconstructed in the archives where they are kept. It means that they were surveyed, measured, and redrawn by digital tools, with the aim of recognizing geometric constructions, alignments, parallelisms, and, mainly, geometric relationships between fortifications elements, sequences of tracing, and shooting lines. Each plate's frame and the graphic scale in "trabucchi" (unit of measurements used in Piedmont until first mid of the nineteenth 
century, equivalent to about $3,0825 \mathrm{~m}$ ) when it is present, have been measured. Then, the fortifications drawings were redrawn by $\mathrm{CAD}$ in true scale, using the millimetre as reference unit, both for measuring the original maps and redrawing the Citadel and the external defences. Finally, CAD drawings have been superimposed to the original maps for verifying the quality of the reconstruction.

\subsection{Working methods and main references for the geometric re-construction}

The survey phase involved the search for the tracing methods of the past taking into account: which instruments (compasses, rulers, set square), which tracing tools (metal points, lapis, pens), which rendering techniques (colours, shading) were in use at that time. The reading of the chapter devoted to the "Instrumenti dell'Architettura" in the Architettura civile by Guarino Guarini could be illuminating in this sense (Guarini, posthumous 1737). Moreover, the constructions of the regular pentagon given by Ptolemy (IV-III b.C.), Dürer (XV-XVI a.C.), Herbert (1689) as well as that by Guarini who divided the round angle in five equal parts of $72^{\circ}$ (1676) have been considered. Guarini's regular fortress, described as a pentagonal citadel in the Trattato di fortificatione (Guarini, 1676), certainly is an important reference for understanding the ideational logic of the so called Modern Fortresses.

Previous studies (Spallone, 2017) highlighted the peculiarities of Guarini's scheme: the geometric concatenation, the regularity of the plan, and the proportion between the parts. In particular, emerged:

- the construction of the pentagon through the division of the angle at the center into five equal parts;

- the division of the side of the interior pentagon into five equal parts, with the middle three delimiting the curtain and the lateral ones indicating the position of the bastion flank perpendicular to the curtain;

- the presence of the second flank between the razant and fichant lines of defence.
These features inspired further analyses about the historical drawings of the Citadel of Turin (Spallone, 2018), and some consideration were proposed in relation to:

- the irregularity of the internal and external pentagon;

- the shape of the bastions;

- the presence of the second flank;

- the geometric relationship between flank and curtain.

Today research widens to the external defences: ravelins, counterguards, demi-lunes, as they were realized, or only designed, over the centuries, and their relationships with the Citadel. The selected drawings can be classified as in scale survey drawings, but some of them also represent artefacts in project or under construction.

A significant precedent for the present analysis is the survey drawing by Carlo Morello published in a large format book (400 x $460 \mathrm{~mm})$ (Morello, 1656), which analysis revealed a substantial consistency with the measurements stated by Fara (Fara, 2001). The main features of the Citadel drawn by Morello are: the application of Dürer's method for constructing the interior pentagon (thought to be regular) on the plot, as demonstrated by the location of the well (Fara, 2001); the different measurements of the curtains; the length of the curtain about $3 / 5$ of the side of the interior pentagon; the presence of the second flank more or less pronounced on the five curtains, varying in length from about onefifth of the curtain almost to zero, along the shorter curtains.

\subsection{Results of the graphical analyses}

Some years later, Michel Angelo Morello, son of Carlo Morello, drew the Citadel as a part of an incomplete collection of Military Drawings which were identified by Viglino and Bonardi. Morello's drawing about the Citadel was presumed to be either a copy of or preparatory drawings (Viglino Davico, Bonardi Tomesani, 2001) for the Theatrum Sabaudiae, and dated 1663-1664 by Peyrot (Peyrot, 2000). The graphical reconstruction of Michel Angelo Morello's drawing leads to the hypothesis that it was born 
from a regular pentagon based on the side of the Mastio. The adjacent sides coincide with the sides of this regular pentagon, although they are shorter, and the sides towards the countryside are parallel with those of the regular pentagon. Each side of the interior pentagon is divided into five parts, as Guarini proposed a few years later, with $1 / 5$ delimiting the position of the bastions and leaving $3 / 5$ for the development of the curtain. Even all the razant lines of defence converge in the angles between the flanks of the bastions and the curtains, eliminating the second flanks. Michel Angelo's drawing shows similarity with the survey by his father Carlo about the ratios between the side lengths of the exterior and interior pentagons and that of the curtains, resulting in a similar "squeezing effect", but also a greater search for regularity and the lack of the second flanks, that reveals a different idea of defensive strategy. Also the ravelins seem to be regularized and the razant lines passing for their faces impact the angles between the bastions' faces and the flanks. The well is quite close to the intersection of the circumferences of Dürer's construction.

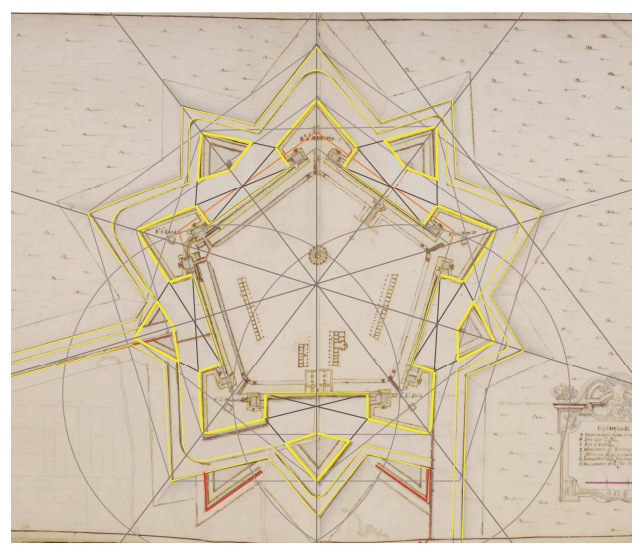

Fig. 1. Michel Angelo Morello, Cittadella di Torino $(740 \times 470 \mathrm{~mm})$. Graphical analysis and geometric construction superimposed on the original plate. (Istituto di Storia e Cultura dell'Arma del Genio di Roma, Biblioteca 40/b-n.18798. Reconstructive drawing: R. Spallone).

Moreover, there are two demi-lunes, never realized, that flank the ravelin in front of the Mastio.
An anonymous drawing of the Citadel, referable to the Nineties of the seventeenth century, deserves a particular attention. It was accurately drawn, but seems to be unfinished, being the external ramparts and a building inside the Citadel drawn by lapis. It presents a new structure, the "Pastiss" on the capital line of San Lazzaro bastion. The Pastiss (that means jumble for its complex shape) is a casemate, today preserved, built between 1572 and 1574 and featured by a very original trefoil plan. The sharpness of the drawing could be appreciated in several details, e.g. the alignments of the razant defensive lines of the ravelins to the slots for cannons in the adjacent bastions. The interior and exterior pentagon are subject to the same squeezing effect of the Citadel by Michel Angelo Morello, but also to a rotation of the shorter sides towards the inside. Instead, the ravelins maintained the alignment and the parallelism with a regular pentagon. It follows that the capital lines aren't in axis with the ravelins, except that of the bastion opposite to the curtain of the Mastio. Guarini's ratio between the interior pentagon and the curtain is observed and the second flanks are present in all the curtains.

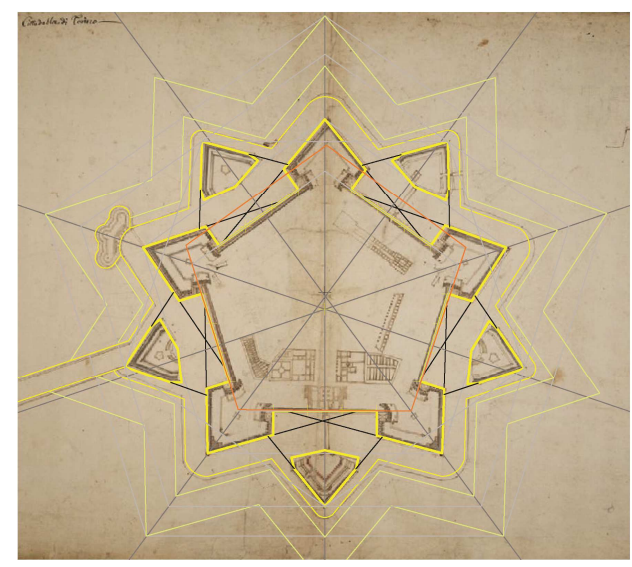

Fig. 2. Anonymous, Cittadella di Torino $(732 \times 507$ $\mathrm{mm})$. Graphical analysis and geometric construction superimposed on the original plate. (Archivio di Stato, Carte topografiche per A e B, Torino 1, Mazzo 1. Reconstructive drawing: R. Spallone).

In the same years a detail of the project for the completion of the city fortifications shows the counterguards realized in front of the three bas- 
tions facing the countryside and the demi-lunes flanking the ravelins, designed, but not built. The particular of the Citadel is in a small scale in relation to the other plates, so it is more evidently regularized, although the proportions of the interior and exterior pentagons are the same of the previous drawings. The faces of the bastions are perfectly aligned with the vertex between the opposite flank and curtain, thereby there isn't the second flank. The faces of the ravelins seem to be aligned with the vertices of the interior pentagon. The south-west ravelin in contact with the walls is aligned with the capital line of the opposite bastion and rotated, probably due to the connection with the wall. The position of the well seems a bit random: it does not respect the construction of Dürer and is asymmetric.

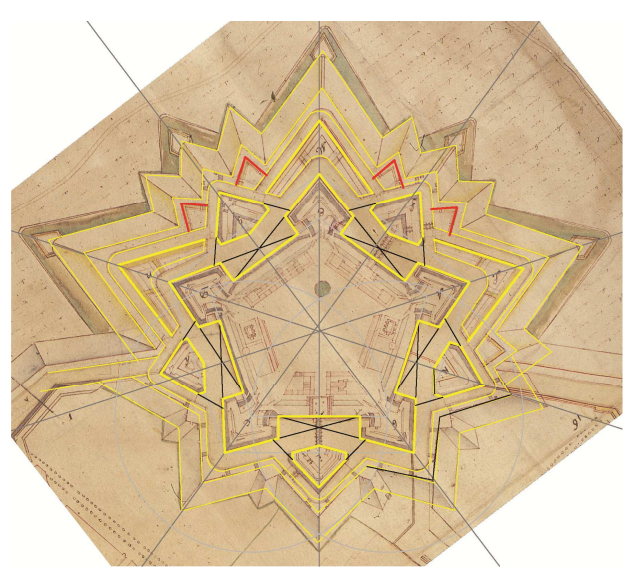

Fig. 3. Anonymous, Projet General pour l'Achevement des fortifications de la Ville et Citadelle de Turin, detail, 100 trabucchi=102 mm (1300 x $857 \mathrm{~mm})$. Graphical analysis and geometric construction superimposed on the original plate. (Archivio di Stato, Carte Topografiche e disegni, Ufficio generale delle finanze, Tipi Sezione II Ufficio generale delle finanze, Torino fortificazioni, mazzo 356. Reconstructive drawing: R. Spallone).

The plan of the Citadel, drawn by Auguste de la Vallée between the Twenties and the Thirties of the eighteenth century shows the underground works. Also in this case the sides of the interior pentagon are aligned or parallel with those of a regular pentagon, while the exterior pentagon has the side on the right of that where the Mastio is located considerably closer than the others to the interior pentagon. It follows that the adjacent bastions are not regular. In relation to the previous drawings analysed, the ravelins have the vertex angle wider than that of the bastions. So, a larger portion of the bastions' faces are protected by the ravelins. All the curtains have the second flank, more or less pronounced. The location of the well seems even more random than in the previous map.

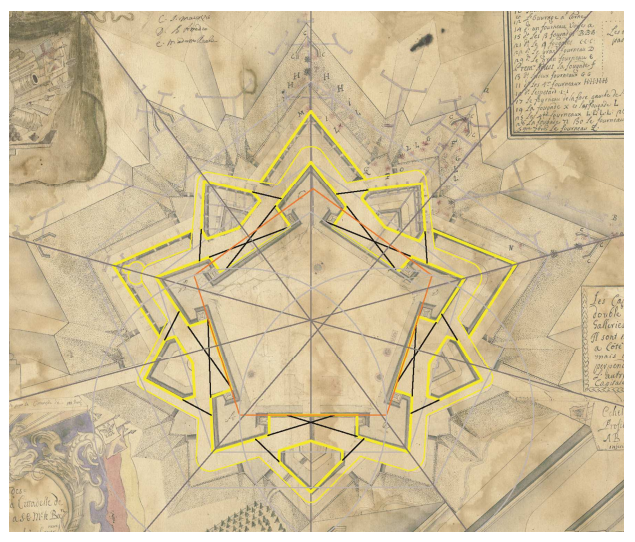

Fig. 4. Auguste de la Vallée, Plan des Sousterrains de la Cittadelle de Turin, 100 trabucchi=147,5 mm (660 x $495 \mathrm{~mm}$ ). Graphical analysis and geometric construction superimposed on the original plate. (Archivio Storico del Comune, SIM D554. Reconstructive drawing: R. Spallone).

The latest drawings among the selection are two maps by Agostino Chiodo, representing the plan of the Citadel and the countermine tunnels, respectively. The first one is dated 1846, and both are reduced in scale 1:2000. The plan of the above-ground structures demonstrates a particular interest in the buildings present inside the Citadel, that are described about their functions and date of construction. It could imagine that the aim of this drawing, realized immediately before the dismantling of the above-ground artefacts, was the documentation of the existing buildings at that date. From the geometric point of view, while the drawing of the Citadel seems very similar to Michel Angelo Morello one, that of the ravelins seems to be inspired to other regulator criteria. Indeed, the axes of the ravelins are coincident with the lines passing from the opposite bastion's vertex and the mid of the curtain, so they are perfectly symmetric with re- 
spect to the curtains and their vertex angle is more pronounced than that of the bastions.

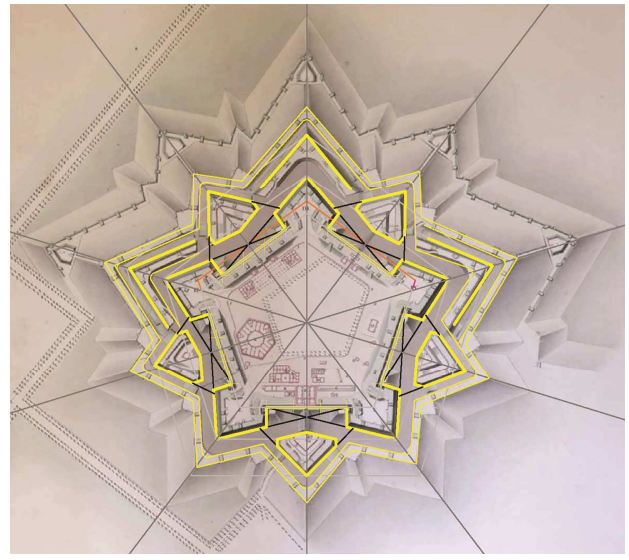

Fig. 5. Agostino Chiodo, Piano della Cittadella di Torino colla distribuzione interna dei varj Edifizi, in Raccolta dei disegni delle fortificazioni esistenti negli Stati di terraferma del Re di Sardegna ordinata da S.M. il Re Carlo Alberto... Graphical analysis and geometric construction superimposed on the original plate. (Biblioteca Reale, Disegni, O.XIII. Reconstructive drawing: R. Spallone).

\section{Underground Archaeological Evidence}

Archaeological research plays an essential role in studies concerning the disappeared citadel of Turin and represent, by now, a real direct source of primary importance for the reconstruction of its fortified plant

Despite the partial demolition of the fortifications, whose remains have been further reduced by over a century of urban development, the evaluation of the potential for archeological remains was a successful operation since the first, although occasional, studies dating back to the years between the end of nineteenth and the beginning of twentieth century. The most important results were achieved with extensive systematic research, aimed at recovering the fortified works still existing in the subsoil, promoted and conducted by Museo Civico Pietro Micca, starting from the end of the 1950s. For over thirty years, moreover, the increasing amount of data deriving from urban excavations, directed by Soprintendenza Archeologia, Belle Arti e Paesaggio per la Città Metropolitana di Torino, has greatly expanded knowledge about the location and consistency of archaeological deposits, of which significant portions have been investigated, documented and, where possible, preserved and open to visitors.

\subsection{The demolition of the citadel and the formation of archaeological deposits}

Downgraded from stronghold to simple barracks area on 9 May 1855, the citadel was disarmed and progressively dismantled with the Regio Decreto of 22 May 1856, saving only the main gate, the Maschio. As foreseen in the new city expansion plan, Progetto di ingrandimento della Città di Torino verso l'ex-Cittadella, approved on 5 April 1857, the demilitarized area was destined to be urbanized (Comoli, Fasoli, 2000). As confirmed in several excavations, the results of demolitions, which were concluded in the last years of the nineteenth century, were very uneven and strictly dependent on the intended use of the plots of land of the new city district. In general, the upper section of bastions, curtains and detached works was removed up to $0,75-1,00 \mathrm{~m}$ below the level designed for the new roads, which in turn corresponded to floor level of the covered way above the counterscarp. Therefore, below the non-built areas, such as streets, squares or the courtyards of the buildings themselves, the lower sections of the fortification works still remain, in some cases up to 3-4 m high, and, although filled, the cellars of magazines, barracks and other logistic buildings. The radical destruction of the fortified works is instead documented, for the most part, where the excavations of the new buildings led to the deep tampering of the subsoil, interfering in many cases also with the countermines galleries placed at the highest level of the underground defensive system, at meters 5-6 of depth. The underground installations placed at greater depth, however, did not suffer structural damage although, in many cases, were "rationally" used as disposal areas for the materials extracted during excavations.

Until the early twentieth century the remains of the fortifications demolished and buried, sometimes found during municipal works carried out 
on the former citadel's grounds, which produced further destruction, were not object of attention. The archaeological excavation carried out by Riccardo Brayda in 1890, in order to recover the sixteenth century Pozzo Grande (Great Well), designed by Francesco Paciotto in the inner square of the citadel and famous for the double helical ramp, was an isolated attempt, almost immediately interrupted for economic reasons (Zannoni, 2000).

\subsection{The recovery of buried fortifications}

In the early twentieth century, the bicentennial celebrations of the siege of 1706 were the starting point for the first systematic studies and restoration works. Research and excavations, restarted in the second half of the century, were specifically directed, wherever possible, on the most significant elements of the Citadel, summarized below.

In 1909 the discovery of a section of the detached work called "Mezzaluna del Soccorso" and a part of its countermine system was the basis for three topographical studies published, between 1910 and 1913, by Colonel Pietro Magni. These works, based on the integration between evidence and archival sources, contributed, for the first time, to the preservation of the galleries found, that were open to visits since 1913 and, then, used as shelters during the Second World War. These studies also formed the basis for the subsequent research of Colonel Guido Amoretti, begun in the second half of the 1950s. After the foundation of the Pietro Micca Museum, in 1961, the projects of exploration, study and recovery were extended, by Guido Amoretti, to the entire countermine system (Bevilacqua, Zannoni, 2007). The system consisted of five pairs of main capitals galleries, connected with masonry stairs, placed at m- 6 and m-13 below the glacis of the bastions and ravelins facing the countryside. Four smaller systems, formed by a single capital gallery, guaranteed the defense of the glacis and covered way in the sectors included between bastions and ravelin. A magistral gallery, which ran under the covered way, constituted the underground communication among galleries of the different ramparts. Finally, from the main galleries, a series of mine branches were excavated, where the counterminers could plant their charges of gunpowder. Wrongly considered of sixteenth-century origin, this auxiliary work, designed by the piedmontese engineer Antonio Bertola, has recently been dated, based on data obtained from unpublished archival sources, to the years 1705-1709, excluding some short sections dating back at the end of the seventeenth century (Bevilacqua, Zannoni, 2006).

The recovery of a large part of the countermine system involved in the underground battle in 1706 , contributed to providing new perspectives for the study, currently in progress, of the underground battlefield, associating the data obtainable from the archaeological evidence documented, in emergency conditions, by Guido Amoretti in the 1950s, and those that emerged from the most recent investigations and surveys, conducted by members of the Museo Pietro Micca, on sites of fighting between opposing miners.

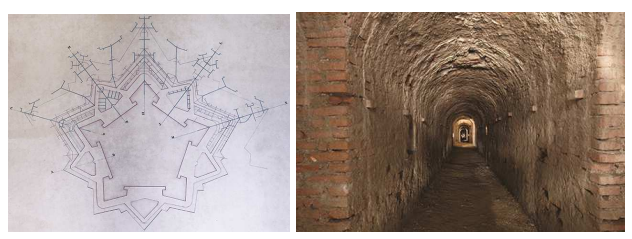

Fig. 6. Left: Agostino Chiodo, Piano Generale delle Contromine della Cittadella di Torino, in Raccolta dei disegni delle fortificazioni esistenti negli Stati di terraferma del Re di Sardegna ordinata da S.M. il Re Carlo Alberto... (Biblioteca Reale, Disegni, O.XIII). Right: General view of the lower capital gallery in the countermine system of the ravelin "del Soccorso" (P. Bevilacqua).

Another important topographical reference was given by the excavations, carried out by the Associazione Amici del Museo Pietro Micca, of the sixteenth-century external defense known as "Pastiss". Built between 1572 and 1574, by order of Duke Emanuele Filiberto di Savoia, with a project by Ferrante Vitelli, the casemate was located inside the main ditch of the Citadel, in front of the bastion San Lazzaro. The main front was characterized by a profile en trefle, with a countermine gallery inside the foundations, below the bottom of the ditch. The section emerging from the ground was internally formed of two floors, covered with barrel vault, both with a 
regular series of embrasures for the defense of the edge and the bottom of the external ditch. The gorge towards the bastion defended the main ditch by means of small cannons, placed behind embrasures open through the wall. A large gallery guaranteed communication with the citadel. In 1705 the Pastiss was incorporated into the new counterguard San Lazzaro, losing any defensive function (Amoretti, Menietti, 2000). Largely spared from nineteenth-century demolitions, the Pastiss has been the subject of a research and safeguard project, begun since 1976, culminating, in 2014, in the restoration of the entire recovered western section.

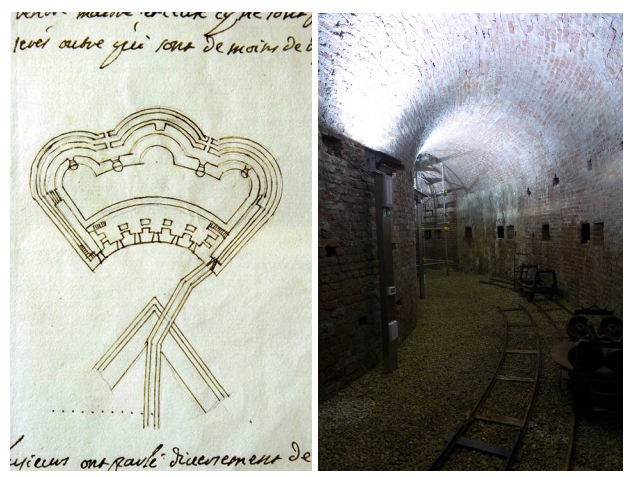

Fig. 7. Left: Louis Guibert, [Pianta del Pastiss], 1702. (Archivio di Stato, Materie Militari, Intendenza Generale Fabbriche \& Fortificazioni, Mazzo III Inv., f. 4v). Right: View of the western section of Pastiss at the end of the 2014 restoration (S. Bigando).

The excavation of the Pozzo Grande, located exactly below the school building Ricardi di Netro, is the last, in chronological order, of main objectives pursued by Museo Pietro Micca. The structure was largely completed between 1565 and 1567. The hypogean section was characterized by two superimposed and independent helicoidal ramps, running inside two concentric masonry cylinders, to lead the quadrupeds of the garrison to the watering at groundwater and, then, return to the surface. At the summit the well was crowned by an elegant two-storey building, a columned loggia above an arcaded portico, completed in 1607. Authorized by the Soprintendenza, the excavation was carried out in two phases, in 1995 and 2006. An exploration well was positioned next to the sixteenth-century structure and dug up to its maximum estimated depth. Two short horizontal tunnels were dug to a depth of $m-5$ and $m-13$ to gain access to the interior. The deepest tunnel brought to light the lower end of one of the two ramps, and the access arch to the basin for watering. The upper part of the ramps, however, was completely demolished before the complete burying of the well, at the end of the brief siege of 1799. The exploration well used during the excavations allows today the visit to the recovered structures.

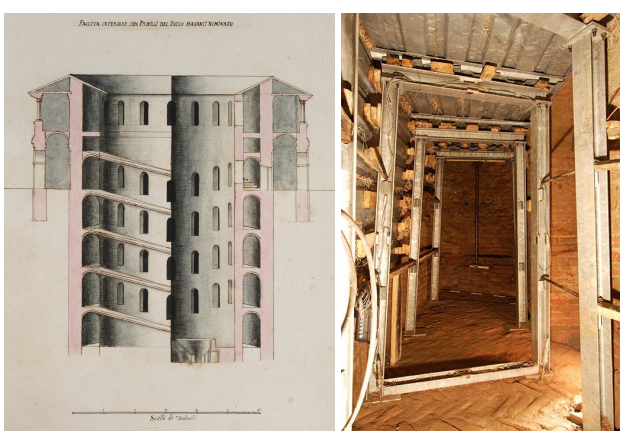

Fig. 8. Left: Michel Angelo Morello, Facciata interiore con Profili del Pozzo havanti nominato (Istituto di Storia e Cultura dell' Arma del Genio di Roma, Biblioteca 40/b-n.18798). Right: The lower terminal of a helical ramp at the end of the 2006 excavation phase (P. Bevilacqua).

\section{Conclusion}

The documentation and recovery operations briefly summarized, represent the result of a century of fieldworks, particularly significant if considered in relation to the era in which they started, where the concept of preserving the remains of this nature and chronology was not established at all. The topographical landmarks represented by the recovered evidence, constitute today a fundamental element of reference for the protection activity carried out by Soprintendenza, culminated in 2017 in the creation of a new archaeological area, containing the remains of the ravelin "degli Invalidi" and the related logistic structures, the first surface fortified works brought to light definitively since the time of their partial demolition. The validity of the results obtained from the interpolation of material evidence with archival data is undoubtedly a strong stimulus both to develop research in the field of conflict archaeology, as the study of the 
underground battlefield of 1706 is already proving, both to continue to investigate, in terms of reconstructive design, the themes related to the relationships between geometry, architecture and firearms.

\section{Notes}

While the research is the result of the collaboration between the authors, paragraphs 1 and 4 were written by R. Spallone and F. Zannoni, paragraph 2, 2.2, 2.2 by R. Spallone, paragraph 3, 3.1, 3.2 by F. Zannoni.

\section{Bibliography}

Amoretti, G.; Menietti, P. (2000). "Riscoperta e valorizzazione del forte torinese detto «Pastiss»", in Amoretti, G.; Petitti, P., eds., La scala di Pietro Micca 1958-1998: Atti del Congresso Internazionale di Archeologia, Storia e Architettura Militare, 11-13 novembre 1998, Torino, Camedda \& C. snc., Torino, pp. 31-55.

Bevilacqua, P.; Zannoni, F. (2006). Mastri da muro e piccapietre al servizio del Duca. Cronaca della costruzione delle gallerie che salvarono Torino, Giancarlo Zedde, Torino.

Bevilacqua, P.; Zannoni, F. (2007). "Le «gallerie di Emanuele Filiberto». Breve storia di un luogo comune", in Mola di Nomaglio, G.; Sandri Giachino, R.; Melano, G.; Menietti, P., eds., Torino 1706. Memorie e attualità dell'assedio di Torino del 1706 tra spirito europeo e identità regionale: Atti del convegno, 29-30 settembre 2006, Centro Studi Piemontesi, Torino, pp. 291-336.

Comoli, V.; Fasoli, V. (2000). 1848-1857. La Cittadella di Torino, Archivio Storico, Torino

Fara, A. (2001). "Geometrie della fortificazione e architettura da Borromini a Guarini", Mitteilungen des Kunsthistorischen Institutes in Florenz, 45(1-2), pp. 103-189.

Guarini, G. (1676). Trattato di fortificatione, che hora si usa in Fiandra, Francia, et Italia; composto in ossequio del sereniss. principe Lodovico Giulio cavagliere di Savoia, Appresso gl'heredi di Carlo Gianelli, Torino.

Guarini, G. (1737). Architettura Civile, Gianfrancesco Mairesse, Torino.

Morello, C. (1656). Avvertimenti sopra le fortezze di S.R.A. del Capitano Carlo Morello primo ingegniere et logotenente generale di Sua arteglieria, Biblioteca Reale di Torino, Ms. Militari 178; Facsimile ed., Biblioteca Reale di Torino, Consiglio Regionale del Piemonte, Torino, (2001).

Peyrot, A. (2000). "Le immagini e gli artisti", in Roccia, R. ed., Theatrum Sabaudiae. Teatro degli Stati del Duca di Savoia, Archivio Storico della Città di Torino, Torino, pp. 31-65.

Spallone, R. (2017). “The «Regular Fortress» by Guarini and the Citadel of Turin”, Nexus Network Journal, 19 (2), pp. $255-277$.

Spallone, R. (2018). "The Citadel of Turin «in Absentia». Drawings and Reconstruction Hypotheses after Demolition", in Marotta, A.; Spallone, R., eds., FORTMED 2018. Defensive Architecture of the Mediterranean: International Conference on Modern Age fortifications of the Mediterranean coast, 18-20 October 2018, Torino, Politecnico di Torino, Torino, pp. 249-256.

Viglino Davico, M.; Bonardi Tomesani, C. (2001). Città munite, fortezze, castelli nel tardo Seicento. La raccolta di disegni 'militari' di Michel Angelo Morello, Istituto Italiano dei Castelli, Roma.

Zannoni, F. (2000). "Le fonti documentarie del Cisternone della cittadella in relazione con il dato archeologico", in Amoretti, G.; Petitti, P., eds., La scala di Pietro Micca 1958 - 1998: Atti del Congresso Internazionale di Archeologia, Storia e Architettura Militare, 11-13 novembre 1998, Torino, Camedda \& C. snc., Torino, pp. 77-133. 